\title{
СУБ’ЄКТИВНИЙ АСПЕКТ У СЕМАНТИЧНИХ ТРАНСФОРМАЦІЯХ СЛІВ
}

Одним із надзвичайно важливих аспектів дослідження складної та багатогранної проблеми семантичних трансформацій слів у ході їх використання є аналіз специфічних закономірностей людської психіки й особистісних якостей людини, які впливають на характер сприйняття світу та щзо зумовлюють изі трансформації.

У мовознавстві заведено розмежсовувати дві основних групи таких чинників: 1) зовнішні (позамовні) та 2) внутрішні (власне мовні). У статті розглянемо суб'єктивний аспект, який насамперед слід ураховувати, на нашу думку, вивчаючи семантичні перетворення слів у поетичних текстах.

Загалом до иієї групи належить иціла низка найрізноманітніших явищ із соціального, культурного, економічного та політичного життя відповідної епохи, вплив яких на семантику слів у цілому $і$ в художньому тексті зокрема величезний. Однак не тільки такого типу чинники визначають особливості використання мовних одинищь у художньому творі. Аналізуючи поетичний текст, винятково важливого значення набуває необхідність розкриття закономірностей розумових процесів пізнавальної діяльності автора, виявлення різних комбінацій елементів його естетичного пошуку. Така діяльність, як і ї̈ результати, емоційно забарвлена та надзвичайно яскраво виявляється в поетичних творах і впливає, крім іншого, на особливості значень використовуваних слів.

Слово - мовна одиниця, яка набуває саме того значення, яке витворюється в прочесі пізнавальної практики людини, однак у художньому творі його семантика визначається не тільки загальномовним значенням, а й особливостями індивідуальної гносеології та когнітивної діяльності. Водночас, виражаючи свою думку або відтворюючи мовну картину, повідомляючи про будь-які події, людина не може повністю абстрагуватися від власного ставлення до висловлюваного й так або так дає йому свою оцінку. 3 гносеологічного погляду будь-яка пізнавальна або мовна діяльність стає виявом відтворення суб'єктом об'єктивних явищ. Внутрішній світ людини, його особисте «я» передбачають творче декодування дійсності та накладають певний відбиток на ті образи, щзо формуються у свідомості під упливом предметів та явищ навколишнього світу.

Ключові слова: слово, семантика, поетичний текст, семантичні трансформацї, когнітивна діяльність.

Tetyana BABYCH, orcid.org/0000-0002-0174-623X Candidate of Philological Sciences, Associate Professor at the Department of the Ecology and Environmental Protection Central Ukrainian National Technical University (Kropyvnytskyi,Ukraine) babichtetyana1211@gmail.com

\section{SUBJECTIVE ASPECT IN SEMANTICAL TRANSFORMATIONS OF WORDS}

One of the extremely important aspects of studying the complex and multifaceted problem of semantic transformations of words in their use is the analysis of specific patterns of the human psyche and personal qualities that affect the nature of perception of the world and cause these transformations.

In linguistics, it is customary to distinguish between two main groups of such factors: 1) external (extralinguistic) and 2) internal (actually linguistic). In this article we will consider the subjective aspect, which should be taken into account, in our opinion, when studying the semantic transformations of words in poetic texts.

In general, this group includes a number of diverse phenomena from the social, cultural, economic and political life of the era, the impact of which on the semantics of words in general and in the literary text in particular is huge. However, not only this type of factors determine the peculiarities of the use of language units in a work of art. Analyzing the poetic text, the need to reveal the patterns of mental processes of the author's cognitive activity, to identify various combinations of elements of his aesthetic search becomes extremely important. Such activity, as well as its results, is emotionally colored and extremely brightly shown in poetic works and influences, among other things, features of meanings of the used words.

A word is a linguistic unit that acquires exactly the meaning that is created in the process of human cognitive practice, but in a work of art its semantics is determined not only by the common language meaning, but also by the peculiarities of individual epistemology and cognitive activity. At the same time, expressing one's opinion or reproducing the linguistic picture, reporting on any events, a person cannot completely abstract from his own attitude to what is being said and one 
way or another gives it his assessment. From an epistemological point of view, any cognitive or linguistic activity is a manifestation of the subject's reproduction of objective phenomena. The inner world of man, his personal "I" provide a creative decoding of reality and leave a certain imprint on the images that are formed in the mind under the influence of objects and phenomena of the world.

Key words: word, semantics, poetic text, semantic transformations, cognitive activity.

Постановка проблеми. Сучасні дослідники неодноразово звертали увагу на те, що пізнавальна діяльність людини має як суспільний, так і суб'єктивний характер. Сприймаючи інформацію з навколишнього світу або повідомляючи іiї, люди співвідносять цю інформацію із загальноприйнятими в цьому соціумі поняттями й уявленнями, які зберігаються значною мірою в мові (зокрема, в семантиці мовних одиниць). 3 іншого боку, лінгвісти дедалі більше усвідомлюють важливість дослідження різних аспектів семантики слова, адже саме слово спрямоване виражати особистісне ставлення до світу та слугує найважливішим засобом комунікації.

Аналіз досліджень. Положення про те, що слово в художньому тексті відрізняється від загальнонародного його вживання $\mathrm{i}$ визначається як «робота духу» автора, отримало розробку в працях Л. І. Бєлєхової, Г. О. Винокура, О. Ю. Карпенко, В. І. Кононенка, М. П. Кочергана, Ю. С. Лазебника, М. Р. Мельник, М. О. Рудякова, О. О. Потебні, В. М. Русанівського, О. О. Семенець, Н. В. Слухай (Молотаєвої) та інших учених.

Мета статті - встановити суб' єктивний аспект семантичних зсувів у літературно-художньому мовленні та їхню роль у поетичному дискурсі Ліни Костенко, Василя Симоненка.

Виклад основного матеріалу. Ураховуючи суб'єктивний характер мовлення, зазначимо, що автор поетичного тексту в рамках когнітивнодискурсивної парадигми створює художню комунікацію, спрямовану на пошук нового смислу, переусвідомлюючи зміст слова та створюючи індивідуальний мовний образ, який віддзеркалює авторське бачення світу, його погляд на факти, явища, предмети. Суб' єктивний світ автора в сучасній літературі визначається його пізнавальними здібностями й представлений безпосередньою проекцією буття, що оточує людину, інтерпретує ці реалії та утворює начебто власну реальність. Особливості відтворення й сприйняття дійсності виражаються в тому, що особистісне ставлення до світу стає засобом створення поетичного дискурсу. Іншими словами, зміст твору будується не довільно, а індивідуальним ставленням митця художнього слова до мови.

Суб'єктивний чинник на мовленнєвому рівні знаходить відбиток в індивідуальному ставленні суб'єкта до предметів та явищ, закріплених у мові.
Об'єднання реальності зовнішньої та внутрішньої (авторської) створює текст, здатний упливати на читача з особливою силою. У результаті цього «функціонування мови розглядається як різновид когнітивної діяльності, а когнітивні механізми та структури людської свідомості досліджуються через мовні явища» (Штерн, 1998: 168).

Звертаючи на це увагу, О. О. Семенець зазначає: «Суб'єктивна природа людського мовлення якнайяскравіше виявляється у сфері словесно-художньої творчості, де в мистецькому синтезі нероздільно поєднані об'єктивно-зображальні та суб'єктивновиражальні чинники» (Семенець, 2004: 18).

Тому на сучасному етапі розвитку лінгвістики все більше уваги приділяють проблемі вивчення мови у зв' язку з діяльністю й особистістю людини, iï здатністю сприймати й оцінювати факти дійсності.

Ще О. О. Потебня відкрив та обгрунтував закон зміни значення слова в разі перенесення із загальновживаної сфери в художню, і навпаки. Феноменальні за своєю суттю думки О. О. Потебні про сполучення об'єктивної реальності та багатогранність відбитку природи у свідомості письменника стали фундаментом вчення про семантичну двоплановість слова в художньому мовленні. Злет фантазії в осмисленні людиною реального світу зумовлені відхиленням від мовної норми в певному контексті поетичного дискурсу та когнітивною діяльністю митця.

3 когнітивного погляду словникове значення слова не містить думки, а лише відкриває до неї доступ, і тому першорядне місце в художньому мовленні посідає зміст, ситуативно значущі семантичні компоненти, а не мовне значення концептуального знака. При цьому в результаті порушення закономірностей мовного механізму виникають аномальні висловлювання з незвичною змістовою сполучуваністю, в яких значення його (часом діаметрально протилежних первинному змістовому наповненню) вступають у відносини протиріччя зі значенням, яке відоме всьому колективу.

Семантичні перетворення, які визначаються дією суб' єктивного чинника, представляють відоме слово абсолютно несподівано, наче в іншому вимірі існування. Таке художнє перетворення дійсності має своєю духовною передумовою продуктивне уявлення і закріплює в тексті нереальне сполучення реальних деталей, як це, наприклад, відбувається 
в таких рядках: «Поклала вишня ліктик на тину» (Костенко, 1980: 202); «карусель ивітастих спідничок" (Костенко, 1980: 208); “Кибиток кочових ребристіхалабуди» (Костенко, 1980:211); «Останні очі квітів торкає морозок» (Костенко, 1980: 213); "Однімуть вашу волю, прикрутять до прогресу» (Костенко, 1980: 214); «I слухав місяиь золотистим вухом» (Костенко 1989: 71); "старі хатки в солом'яних скафандрах» (Костенко, 1989: 73); «ген корів розсипана квасолька» (Костенко, 1989: 92); «i чорні сльози щовковичі капали через тин» (Костенко, 1989: 105); «Малої хвилі відчайдушний схлип» (Костенко, 1989: 131); «Зелені верби руки заламали»(Симоненко, 2004: 213); «Важкувато cone димар»; «Галасує від болю дерево» (Симоненко, 2004; 42).

Наведені приклади підтверджують думку Ш. Бодлера про те, що «уява розкладає світ на складові компоненти і потім, збираючи та поєднуючи їх за законами, які виходять із самих глибин душі, створює новий світ, викликаючи відчуття новизни» (Бодлер, 1988: 400).

Семантичні перетворення в наведених поетичних фрагментах зумовлені, очевидно, особливостями поетичної гносеології. Слова набувають змісту, який не передбачений контекстом, а 3'являється з волі автора у співвіднесенні з його світоглядом, асоціативним поглядом на звичайні предмети, які часто персоніфікуються, «обростають» частинами тіла, як це спостерігаємо в таких рядках: «лоскоче боки мертвих яворів» (Костенко, 1989: 411), «коли ридали сосни янтарем» (Костенко, 1989: 392), «сад щепотів потерхлими губами» (Костенко, 1989: 342), "янтарні спини стовбурів» (Костенко, 1989: 332).

Для поетичного внутрішнього світу автора може бути характерна й власна усталена символіка. Так, із погляду вираження суб'єктивного оцінювання важливою функцією у творах Л. В. Костенко наділені образи геометричних фігур. Особливе семантичне оточення формує складні асоціативнообразні зв'язки, що дозволяють геометричним фігурам виконувати роль символів.

Зокрема, це можна сказати про квадрат. У контексті світової поетичної культури форма квадрата - символ пасивного початку, приземленого існування (КСС, 1994: 239-240). У наведених рядках уживання образу квадрата (квадрат - рівнобічний прямокутник; про що-небудь такої форми (CУM, IV: 127) в одній смисловій конструкції зі словами трати (грати - переплетіння металевих прутів, штаб і т. ін., що використовується для загорожі (СУМ, II: 159), зорі (зоря - самосвітне небесне тіло (СУМ, II: 576) та дамки (дамка шашка, яка після завершення свого ходу по шаш- ковій дошці набуває права пересуватися на необмежену кількість кліток (СУМ, II: 210) утворює своєрідну гру сем 'неволя', 'космічна воля', 'гра', в якій квадратна форма може символізувати ув'язнення, а зорі - шашки, що пересуваються по залізних рамках, під час руху поїзда:

\section{Квадрати-грати,}

залізні рамки, -

можна зорями

грати в дамки (Костенко, (1989: 148).

Квадрат у поезії Л. В. Костенко також символізує бездуховність, примітивізм, втиснутий у «ритуальний штамп»; виражає занепокоєння поетеси вторгненням примітивних інтересів і бажань у земне буття людей, намірами втиснути духовність в обмежені форми:

Номенклатурні дурні, бюрократи,

пласкі мурмила в квадратурі рам

(Костенко, 1989: 169).

Поруч із квадратом трапляється кругла форма (коло - замкнена крива, всі точки якої однаково віддалені від центра (СУМ, IV: 226), яка може сприйматися як евфемізм, покликаний завуалювати прагнення до досконалості:

Обруч - як на діжку. Щоб мислі тримались купи (Костенко, 1989: 234);

Дзвенять у відрах крижані кружальия

(Костенко, 1989: 41);

Замкнулось коло. Вихід замурований

(Костенко, 1989: 195).

Особливу функцію виконує овальна форма (овал - фігура, що має вигляд витягнутого круга (СУМ, V: 610) у В. А. Симоненка. Семантика контекстуального використання слова овал значно ширша, ніж словникова. Авторський овал стає своєрідним амулетом, що здатен зберегти від досади та розпуки.

Де ж ті одні-єдині руки,

Що в час досади і розпуки

Мене сховають в свій овал?

(Симоненко, 2004: 202).

Рідше в розглянутих текстах присутня форма трикутника (трикутник - геометрична фігура на площині, обмежена трьома прямими, які взаємно перетинаються й утворюють кути (СУМ, Х: 259), що символізує єдність i, можливо, початок:

чорні лебеді часу з лебединої пісні сторіч

потім випливають знову

з багряної дельти світанку

(Костенко, 1989: 101).

(Дельта $^{2}$ - назва четвертої букви грецького алфавіту, яка має форму трикутника (СУМ, II: 237), a також дельта $^{1}$ - гирло річки 3 численними острівцями й протоками на замуленій низині (СУМ, II: 237). 
Отже, суб'єктивний чинник проявляється в дії символів та асоціацій, які властиві світобаченню автора та апелюють до «внутрішнього багажу» сучасної системи свідомості. Цей чинник уможливлює використання особистісних мірил осягнення та сприйняття величезного інформаційного простору сучасної культури та життя. Тому асоціативна поетика має масштаб перцептивного «простору уявлення епохи» (Бергер, 1994: 124) і найчастіше є наслідком переосмислення слів в індивідуальному вживанні. Приклад такого переосмислення представлений у таких рядках:

Зажуриться. Ні пари, ані парості.

Мігрень душі... Написано не все

(Костенко, 1989: 234).

Асоціації, які привернули увагу поета, належать до розряду особистісних. Контекстуальне значення слова мігрень відмінне від словникового (мігрень - захворювання людини, що виявляється в періодичних приступах головного болю (СУМ, IV: 724). У наведеному контексті лексема реалізує лише частину свого значення, а саме - сему 'захворювання' (захворювання - занедужання (СУМ, III: 378). Супроводжуючись образними прирощеннями смислу, це значення включається у змістову структуру концепту душа. Отже, повна або часткова відсутність духовного смислу, психічний дискомфорт асоціюється в поетеси 3 мігренню душі (душа - внутрішній психологічний світ людини, що становить суть іiі життя, $є$ джерелом психічних явищ (СУМ, I: 445).

У рядках:

А мені ж, може, просто хочеться щастя,

тугого й солодкого, як шоколад

(Костенко, 1989: 38)

уявлення авторки про щастя земної жінки як туге й солодке зумовлене змістовими компонентами значення слів тугий (тугий - щільно заповнений (СУМ, Х: 310) та солодкий (солодкий - який має приємне відчуття, дає насолоду (СУМ, IX: 446). У результаті співвіднесеності наведених слів у словосполученні туге й солодке щастя значення концепту щастя (щастя - стан цілковитого задоволення життям (СУМ, ХІ: 573) збагачується новими змістовими нюансами. Слово представляє в цьому контексті щастя реально відчутним, повновартісним.

Об'єктивне значення конкретних слів автор художнього твору сприймає суб' єктивно, надаючи імм смислу, відповідного своєму єству, як, наприклад, у рядках:

Кибиток кочових ребристі халабуди

(Костенко, 1989: 403).
Конструкція ребристі халабуди, до складу якої включено слово халабуда (халабуда - убога оселя, хата (СУМ, XI: 12), сприяє переосмисленню лексеми ребристий (ребристий - в якого випинаються ребра (СУМ, V: 468), що містить у собі вказівку на якість живого. Крім того, наведене словосполучення наділене додатковими суб'єктивними семами 'злиденність', 'убогість', які представляють яскраву стилізацію кочового життя.

У такому поетичному рядку:

i стоїть неумитий присмерк за розхристаними дверима

(Костенко, 1989: 135)

відбувається персоніфікація слова присмерк (присмерк - напівтемрява після заходу сонця або перед світанком (СУМ, VIII: 271) завдяки смисловим компонентам лексеми неумитий (неумитий який не вмився (СУМ, V: 268), привертаючи до себе увагу передусім незвичайним смисловим навантаженням. Про присмерк авторка говорить як про людину. А слово двері (двері - отвір у стіні для входу і виходу (СУМ, II: 217) у тому ж прикладі набуває смислових компонентів, властивих живій істоті: розхристані двері (розхристаний - розстебнутий на грудях (СУМ, VIII: 480), у значенні відчинені.

Цікаве переосмислення спостерігаємо в рядках:

I щзо зорю? Який засію лан?

За Чорним Шляхом, за Великим Лугом

Невже і я в тумані-як туман -

і я вже йду за часом, як за плугом

(Костенко, 1989: 4).

Чорний Шлях - це дорога з України до Криму, якою вели невільників у чужоземне рабство. Великий Луг - місце в середній частині Дніпра, нижче острова Хортиці, де сформувалося козацтво. Поставлені поряд, ці дві історичні реалії стають, 3 одного боку, символом намагання ворогів полонити українців, а з іншого - якнайкраще ілюструють героїчну боротьбу та нескореність козацтва. Трансформацію смислу спостерігаємо й у слові плуг, яке в цьому контексті позначає чесну, хоч і важку працю, яку доводиться виконувати наперекір обставинам. Сигналом до виникнення таких індивідуально-авторських асоціацій слугують елементи переносного значення стійкого словосполучення ходити за плугом (обробляти землю (СФУМ, 2003: 293, 402).

Висновки. Отже, художні твори виявляють нові образні смисли лексичних одиниць, що репрезентують ставлення автора до об'єкта зображення та до навколишнього світу.

Внутрішня ємність поетичного змісту слів відкриває асоціативні канали для переосмислення загальнолюдських понять. При цьому когнітив- 
ний аспект осягнення сутності явищ, що оточують людину, включає пізнавальні та психологічні можливості митця із супровідним до них процесом переведення ідеалізованих уявлень в об'єктивну систему знаків. Вербалізована інформація стає когнітивною моделлю зображення світу загалом та окремих його явищ, синтезованим змістом у межах словникового значення.

\section{СПИСОК ВИКОРИСТАНИХ ДЖЕРЕЛ}

1. Бергер Л. Г. Пространство образного мира (парадигма познания) в структуре художественного стиля. Bonpocbl философии. 1994. № 4. С. 124-126.

2. Бодлер Ш. Об искусстве. Москва : Искусство, 1988. 422 с.

3. Костенко Л. В. Неповторність. Київ : Молодь, 1980. 220 с.

4. Костенко Л. В. Вибране. Київ : Дніпро, 1989. 560 с.

5. Керлот Х. Э. Словарь символов. Москва : Reel-book, 1994. 603 с.

6. Рудяков Н. А. Стилистический анализ художественного произведения. Київ : Радянська школа, 1977. 136 с.

7. Семенець О. О. Синергетика поетичного слова. Кіровоград : Імекс ЛТД, 2004. 338 с.

8. Симоненко В. А. У твоєму імені живу. Київ : Веселка, 2003. 382 с.

9. Словник української мови : в 11-ти томах. Київ : Наукова думка, 1970-1980.

10. Словник фразеологізмів української мови / за ред. В. О. Винника. Київ : Наукова думка, 2003. 1104 с.

11. Штерн І. Б. Вибрані топіки та лексикон сучасної лінгвістики. Київ : АртЕК, 1998. С. 15-27.

\section{REFERENCES}

1. Berger L. G. (1994). Prostir obraznoho svitu (paradyhma piznannya) u strukturi khudozhn'oho stylyu [The space of the figurative world (paradigm of cognition) in the structure of artistic style]. Questions of philosophy - Voprosy fylosofyy . № 4. Pp 124-126 [in Ukrainian].

2. Bodler Sh. (1988). Ob yskusstve [About art] Moscow: Iskusstvo, 422 p. [in Russian].

3. Kostenko L. V. (1980). Nepovtornist' [Uniqueness]. Kyiv: Molod', 220 p. [in Ukrainian].

4. Kostenko L. V. (1989) Vybrane [Selected]. Kyiv: Dnipro, 560 p. [in Ukrainian].

5. Carlot H.E. (1994) Slovar' symvolov [Dictionary of symbols]. Moscow: Reel-book. 603 p. [in Russian].

6. Rudyakov N. A. (1977) Stylystycheskyy analyz khudozhestvennoho proyzvedenyya [Stylistic analysis of a work of art]. Kyiv: Soviet school, 136 p. [in Ukrainian].

7. Semenets O. O. (2004) Synerhetyka poetychnoho slova provadzhennya [Synergetics of the poetic word]. Kirovograd: IMEX LTD,338 p. [in Ukrainian].

8. Simonenko V. A. (2003) [U tvoyemu imeni zhyvu] I live in your name. K: Veselka, 382 p. [in Ukrainian].

9. Dictionary of the Ukrainian language [Slovnyk ukrayins'koyi movy. v 11-ty tomakh] / (Vols 1-4). Kyiv: Naukova dumka [in Ukrainian].

10. Dictionary of phraseology of the Ukrainian language [Slovnyk frazeolohizmiv ukrayins'koyi movy] (2003). / ed. V.O. Vinnik. Kyiv: Naukova dumka [in Ukrainian].

11. Stern I. B. Vybrani topiky ta leksykon suchasnoyi linhvistyky]. (1998). [Selected topics and lexicon of modern linguistics]. Kyiv: АртЕК. P. 124-126 [in Ukrainian]. 